\title{
Does it cost more to be a female offender? A longitudinal study of childhood circumstances, crime, drug abuse, and living conditions to age 48
}

\section{Published as: Estrada, F. \& Nilsson, A. (2012): Does it Cost More to be a Female Offender? A life-course study of Childhood Circumstances, Crime, Drug Abuse, and Living Conditions Feminist Criminology, 7: 196-219.}

\begin{abstract}
In this article we use a new and rich longitudinal data set, The Stockholm Birth Cohort Study, which allows us to follow a cohort of girls and boys until they reach 48 years of age. We study differences in the social background and adult living conditions among men and women with different experiences of involvement in crime. It is clear that the female cohort members who have been registered for crime have experienced more disadvantaged childhoods than the males registered for offending. The results also indicate that involvement in crime seems to cost more for females, in terms of social exclusion.
\end{abstract}

\section{Introduction}

A long time has now passed since Heidensohn (1968) presented her now classic critique of criminology's failure to illuminate the phenomenon of female offending. Since then, the research field has evolved considerably, but there are still areas where our knowledge remains limited. One such area involves longitudinal studies of female offenders and similarities and differences in the life courses of males and females respectively. This gap in the knowledge has proved a difficult one to fill, in part because many longitudinal studies have only included males (see for example Laub \& Sampson, 2003; Farrington, Tfofi, \& Gould, 2009; Pulkkinen, Lyyra, \& Kokko, 2009; Piquero, Farrington, Nagin, \& Moffitt, 2010; Soothill, Christoffersen, Hussain, \& Francis, 2010), and in part because those studies that do include females are rarely of a size that permits analysis of the criminal careers of women (see for example the 
conclusions presented in Giordano, Cernkovich, \& Rudolph, 2002, p. 1012; Lay, Ihle, Esser, \& Schmidt, 2005, p. 47; Bergman \& Andershed 2009, p. 175) In addition, on the basis of a review of prospective longitudinal studies which include females, Block, Blokland, van der Werff, van Os \& Nieuwbeerta (2010, p. 75) conclude that very few of these follow women further than young adulthood. A further limitation is that few studies have broadened their analyses to include other gendered adult outcomes than involvement in crime. Thus while it is well established that many more males than females commit various types of crime, there is much less information available on the extent to which the life courses of males and females who have been involved in crime are similar or distinctive.

In this study we compare different groups of males and females defined on the basis of their registered crime at different ages. What similarities and differences can we see in their social background, criminality, drug abuse and living conditions in late mid-life? We employ a new and unique longitudinal data set, The Stockholm Birth Cohort Study (SBC), which allows us to follow a cohort of boys and girls born in Stockholm in 1953 until they reach the age of 48 years.

\section{Should we expect gender differences in the causes and costs of crime?}

Boys and girls share most of the risk-factors associated with juvenile delinquency (for example, Wong, Slotboom, \& Bijleveld, 2010). However, we know less of the existence, or non-existence, of gender differences in the long-term consequences of criminal involvement. Tanner, Davies and O’Grady (1999) use the National Longitudinal Survey of Youth to study the long-term impact of self-reported teen delinquency. They show that delinquency has a negative effect on life-chances, since it reduces the likelihood of educational and occupational achievements in young adulthood (at ages 25-30). For males, juvenile delinquency predicted both a low academic status and a higher risk for unemployment. For the females, however, it 
was only their educational attainment that was negatively influenced by delinquency. Tanner et al. (1999, p. 269) argue that one possible explanation is that this finding reflects the differing role played by employment among males and females respectively.

On the basis of the Dunedin longitudinal study (an analysis of 1000 males and females) Moffitt, Caspi, Rutter, and Silva (2001, p. 46) confirm that both the males and the females who presented conduct disorders in youth had worse living conditions in young adulthood. The males' problems were more often related to the labour market, drug use and crime, whereas the females had worse outcomes in relative terms with regard to relationship problems and physical and mental ill-health. Moffitt et al. (2001) conclude that "the extant literature contains very few actual empirical demonstrations of sex differences in the aetiological factors involved with becoming antisocial, in the correlates of antisocial behaviour, or in its long-term consequences" (p. 5). More recently, Odgers et al. (2008) have presented a study of the Dunedin cohort where they follow the men and women up to age 32 . According to Odgers et al. (2008, p. 706) their study is the first to highlight differences in adulthood between different female offender groups. One important finding is that persistent offenders experience poor outcomes across multiple domains at age 32, and that persistent female offenders experience the most severe consequences in adulthood. Their findings support similarities across gender with respect to developmental trajectories of antisocial behavior and their associated childhood origins and adult consequences.

The link between crime and gendered negative outcomes in later life is more clear in studies that have employed measures indicating involvement in more serious crime (registered rather than self-reported) or that have focused on samples of more serious offenders such as institutionalized individuals (e.g. Simpson, Yahner, \& Dugan, 2008). Results reported by Bergman and Andershed (2009) indicate ${ }^{1}$ that females who were

\footnotetext{
${ }^{1}$ Bergman and Andershed (2009) use data from the IDA longitudinal research program, which follows a cohort of children from a middle-size Swedish city, to illuminate questions about differences between male and female
} 
officially registered for crime during adolescence were at higher risk for a wide range of problems as adults compared to male offenders (see also Molero, 2011). Studies from the Ohio life-course study (OLS) ${ }^{2}$ also show that the females had more negative life outcomes than the corresponding group of males (e.g. Giordano et al., 2002, p. 1012). What offenders of both sexes did have in common, however, was low educational achievement, problematic family backgrounds and poverty (ibid, p. 1052). In another study from the Ohio project Lanctot, Cernkovich and Giordano (2007) conclude that "gender differences were observed in every life domain... these results also indicate that previously institutionalized females face the most adverse conditions during young adulthood" (p. 148).

Why should it cost more to be a female offender? Even if delinquent boys and girls share the same risk factors the considerably lower rate of female offenders indicates that the selection processes into crime may differ for men and women. There is therefore reason to expect it to "take more" to become a female offender. Studies from both sides of the Atlantic have shown that female offenders who end up being dealt with by the justice system have often grown up in very difficult home conditions (e.g. Katz, 2000; Mullings, Pollock, \& Crouch, 2002; Nilsson, 2003; Simpson, 2008). These do not primarily involve resource deficiencies measured in terms of variables focused on SES or coming from a "broken home", but instead more serious social problems, involving for example families characterised by long term poverty, alcoholism, drug addiction, mental illness, child neglect and physical and sexual abuse (for reviews of gendered pathways see Holsinger, 2000; Mullings et al., 2002; Belknap \& Holsinger, 2006). Furthermore, it is also reasonable to expect that women will experience more negative consequences as a result of involvement in crime than male

offenders. However, as they themselves conclude, "The number of females in some of the offender groups is so small that the results /.../ must be interpreted with great caution. Hence, although both genders were studied, the reporting was focused on the results for men" (p. 175).

${ }^{2}$ OLS is a panel study of adolescents originally surveyed in 1982 when they resided in juvenile correctional institutions. The sample includes 127 female offenders and 127 male offenders. A first follow up was conducted in 1995 and a second in 2003 (Giordano, 2010). 
offenders. Female offenders are more stigmatized than men since they not only break the law but also the norms and expectations associated with their femininity (Heidensohn, 1968; Kyvsgaard, 1989, p. 58; Steffensmeier \& Allan, 1996, p. 476). Gorman-Smith and Loeber (2005) conclude that in consequence, the powerful social sanctions directed against the delinquent behaviour of girls mean "that it may take a particularly deviant family to impact risk among girls" (p. 25)

\section{The importance of drug abuse}

In previous studies we have shown that drug abuse is a factor with close links to involvement in crime (Nilsson \& Estrada, 2009; see also e.g. Torstensson, 1987, p. 156ff; Mullings et al., 2002), and which also has consequences for future opportunities and life-careers (see e.g. Sarnecki \& Sollenhag, 1985; Krohn, Lizotte, \& Perez, 1997; Nilsson, 2003; Laub \& Sampson, 2003; Schroeder, Giordano, \& Cernkovich, 2007). This is not least the case in societies where the prosecution of the possession and use of illicit drugs is a priority in the work of the police, and where the explicit goal is that of making it difficult to be a drug abuser (Lenke \& Olsson, 2002). Drug abusers not only risk convictions associated with the handling of drugs (possession or sale) but also for a range of minor offences intended to finance their drug use (Mullings et al., 2002). It is also well-known that drug use is a key element in the socalled "Street Woman scenario"3 (Daly, 1992) which in the literature is seen as a central pathway of female law breaking (e.g. Simpson et al., 2008).

In their analysis of involvement in crime over the life-cycle on the basis of Dutch cohort data, Blokland, Nagin, and Nieuwbeerta (2005, p. 936f) note that the offending of the most criminal group involved a wide range of offence types, of which the majority were

\footnotetext{
${ }^{3}$ According to the Street Woman scenario, childhood trauma and sexual victimization push young women to run away from home. "Life on the street leads to drug use and addiction, which in turn leads to more frequent lawbraking to support a drug habit” (Daly, 1992, p. 13; see also Hagan \& McCarthy, 1997).
} 
less serious property offences. The persistent group also tended to perform poorly in both professional and personal life-course domains (Blokland et al., 2005, p. 936). One limitation of the study is that it does not illuminate the question of whether, and in what ways, the results are specific for male offenders or are also applicable to females. In their discussion of the results, Blokland et al. (2005, p. 945) argue that one possible explanation for the crime pattern exhibited by the persistent group is that the group is largely comprised of drug addicts who commit offences in order to finance their drug abuse. Blokland et al. found it difficult to examine this question further in their own study, however, since they lacked reliable data on drug abuse among the members of the cohort. It is noteworthy that in Tanner et al.'s study (1999, p. 266f), drug use was not such an important factor in predicting negative outcomes in young adulthood for either males or females. However, the study in question is based on selfreport data and does not separate the more serious use of illegal drugs from alcohol use. The fact that we in the present study will look more closely at the significance of drug abuse for the risk for social exclusion in mid-life for different offender groups of both sexes has therefore potential to be a significant contribution to the literature.

\section{Objectives and research questions}

By comparing the lives of delinquent boys and girls we aim to increase our understanding of gender-specific and gender-neutral long term consequences of criminal involvement. The fact that we study both sexes, thus expanding the research field to describe not only the reality of men, but also that of women, is clearly one of the strengths of this study. To our knowledge, this is one of the first studies that are able to analyse the significance of involvement in crime, childhood circumstances and drug abuse for living conditions up to late mid-life, while at the same time including comparisons of males and females. Our main research question centres on how life turned out in late mid-life for boys and girls with different levels of involvement 
in crime. Does it take more, in terms of childhood risk factors, and cost more, in terms of long-term negative consequences, to be a female offender?

Our outcome measures in late mid-life focus on labour market attachment, income and family situation. In the following we present the Stockholm Birth Cohort Study and describe the way variables have been operationalized. The results section begins with a presentation of the crime, drug abuse, and social situation of the males and females respectively during childhood and adolescence. We then move on to describe living conditions in late mid-life. The presentation of findings concludes with multivariate analysis of the associations between gender and the social exclusion of different groups of offenders in mid-life, which include controls for both differences in drug abuse and in other conditions during childhood and adolescence.

\section{Data - The Stockholm Birth Cohort Study}

The Stockholm Birth Cohort Study (SBC) is a longitudinal database created by combining two data sets (for a more detailed description, see Stenberg \& Vågerö, 2006; Stenberg et al., 2007). The first of these is the Metropolitan Study, which comprises all individuals born in 1953 and living in Stockholm ten years later (Jansson, 1995). The Metropolitan data set includes a large amount of register-based and survey data relating to both the parents and the individuals themselves. For almost the entire length of the Metropolitan project (1963-1986) data were collected from a range of different registers. The data set includes information on amongst other things income, social welfare recipiency, social group, educational achievement, hospital treatment, interventions from Child Welfare Committees and involvement in crime (for criminological studies that have used this data set see for example Fry, 1985; Wikström, 1987, 1990; Torstensson, 1987, 1990; Kratzer \& Hodgkins 1999). The other data set, to which the Metropolitan study has been linked, is the Health, Illness, Income 
and Employment database (the HSIA 1980-2001). This database is comprised of register data on all individuals living in Sweden in either 1980 or 1990. The data set we have been able to use for the current study includes information on amongst other things income, welfare benefit recipiency and family type. ${ }^{4}$ Since both databases had been anonymised, a probability matching procedure has been employed. It was possible in this way to match a total of 96 percent of the observations in the Metropolitan study - 14,294 individuals. ${ }^{5}$ The combination of the two data sets means that it is possible to follow the original cohort of individuals born in 1953 until year 2001 when they were 48 years of age.

\section{Criminality and drug abuse}

The information on the cohort members' criminality is drawn from the official police register of criminal records. The register contains information on offences that have either resulted in a conviction or, in cases involving younger offenders, been reported to the Child Welfare Committee. For each year from 1966 up to the first six months of 1984, i.e. the year when the cohort members were 31 years of age, the data set contains information on the number and type of offences committed. These offences have been divided into seven categories:

Violence, Theft, Fraud, Vandalism, Motoring offences, Drug offences and Other offences (Wikström, 1987; 1990). We proceed on the basis of a categorisation that distinguishes four different groups on the basis of their criminal activity at different ages (other longitudinal studies have employed similar classifications see e.g. Eggleston \& Laub, 2002; Lay et al., 2005; Farrington et al., 2006, 2009; Bergman \& Andershed, 2009): (1) No crime: those

\footnotetext{
${ }^{4}$ For this study we have had restricted access to the HSIA data (especially regarding the health/illness variables).

5 The matching procedure involved identifying unique combinations of the variables included in both data sets for the individual study subjects. Probability matching is inferior to matching based on personal identification numbers. However, in this case there are few unmatched individuals $(4.4 \%)$ and the differences between matched and unmatched (excluded) are small (for a detailed description of the matching procedure, see Stenberg et al. 2007).
} 
individuals who have never been registered for crime. (2) Desisters: those who desist from crime prior to the age of 20. (3) Late onset offenders: individuals who are registered for crime for the first time after the age of nineteen. (4) Persisters: those who persist in crime, i.e. individuals who were registered for crime both during their youth and as adults.

The question of typologies and classifications of offenders has been the subject of some considerable debate, a discussion that has focused on both theoretical and methodological issues (Skardhamar, 2010). We make no claims that our classification distinguishes homogenous categories with distinctive careers. By means of our division of the study subjects, we distinguish between those who desisted from crime before the transition from youth to adult life and those who were registered for crime as adults. Failure in the transition to adult life, a phase where occupational careers and family formation are initiated, has been shown to have a long term negative impact on future attainment (Bäckman \& Nilsson, 2011). As will be seen below, we are also able on the basis of this rather simple division of the study subjects to differentiate between individuals with very different levels of involvement in crime. The SBC includes three different pieces of data relating to the prevalence of drug abuse, which capture the situation both in adolescence and early adulthood (for a further description see Appendix). Together these official sources provide us with a picture of the cohort members' registered drug abuse from age thirteen (1966) to age thirty (1983).

\section{Measures of the cohort members' situation during childhood and adolescence}

Our measures on circumstances during childhood and adolescence are taken from different registers (see Appendix) and capture SES, Poverty and Social problems in the family of origin. These are measures that we know to be correlated with the cohort members' registered criminality (Nilsson \& Estrada, 2009), and also with social exclusion in mid-life (Bäckman \& 
Nilsson, 2011). In our final models we also include controls for Cognitive ability (results from mental tests conducted when the cohort members were thirteen years old) and School performance, which is measured by school grades in year nine of compulsory school (age 16).

\section{Measures on the cohort members' situation in late mid-life}

Our outcome measures in late mid-life relate to Labour market attachment, Income, Social exclusion, Family status and Mortality. These are all constructed from population-based register data (see Appendix). Family formation and marital status are measured at two time points: 1991 and 2001. A common child (or marriage) is a prerequisite to be counted as a cohabiting couple. To study formal labour market attachment we have divided the cohort into different groups on the basis of their employment status and income in 2001. As a first step, the cohort members were divided into groups on the basis of annual earnings recalculated into what are referred to as Price Base Amounts (PBA). ${ }^{6}$ The category in employment is comprised of those earning at least 3.5 PBA. This threshold was set to correspond to the lowest amount on which individuals can support themselves for a year. ${ }^{7}$ The group Unstable labour market attachment includes those earning between 1 and 3.5 PBA. The category No labour market attachment is comprised of those with a very low income (below 1 PBA), or no income at all. We also created categories that distinguish those on disability pensions and students. With regard to income, we divided the cohort into three groups - those with the lowest 20 percent of incomes, the highest 20 percent, and the remainder.

Our measure of social exclusion distinguishes the proportion who at age 48 were either outside the labour market (those with either no labour market attachment, or on disability pensions) or were in receipt of social welfare benefit. Being unemployed is to be

\footnotetext{
${ }^{6}$ Annual earnings consist of income from work and work related social insurance programs such as sickness benefits and parental insurance, but do not include pensions and unemployment insurance.

${ }^{7}$ The size of the Price Base Amount is tied to the consumer price index. In 2007 the PBA was specified at approx. 4000 Euros/5500USD.
} 
denied both a certain type of social relations and access to a social institution, the labour market, of which most people of working age are members. Similarly, financial poverty denies people full access to a social activity that is taken for granted by most members of modern societies, i.e. consumption. Labour market exclusion and poverty do not fully account for the multi-dimensionality associated with social exclusion, but it nonetheless captures two of the most important dimensions of this construct. According to Burchardt (2000) exclusion from production activities and financial poverty appear as the most central indicators of social exclusion.

\section{Results}

\section{Crime among females and males}

As expected, we find substantial differences in criminal participation (Table 1). Seven percent of the female cohort members had been registered for offending up to the age of 31 as compared with 33 percent of the males. These proportions are similar to those reported in other studies (Moffitt et al., 2001, p. 214; Eggleston \& Laub, 2002; Bergman \& Andershed, 2009). There are approximately nine males for each female among the persisters. The overrepresentation of males is much less marked among the desisters and the late-onset offenders (approximately four males for each female). ${ }^{8}$ A larger proportion of the female offenders were registered for their first offence subsequent to the teenage years ( $44 \%$ as compared to $31 \%$ ) which is in line with the results of other studies, which have shown that females have a later age of onset for crime (Stattin, Magnusson, \& Reichel, 1989; Eggleston \& Laub, 2002; Simpson et al., 2008; Block et al., 2010).

\footnotetext{
${ }^{8}$ Comparisons of the outcomes for the four groups (prevalence) have been conducted in part using the chi-square test, and with the F-test (ANOVA) when the focus is directed at differences in mean values. Females have been compared to the corresponding male offender groups, i.e. in Table 1, the mean of 3.6 offences as youths among female persisters is significantly lower than the mean of 11.7 offences noted in the corresponding group of males.
} 
Almost half of the men that were registered for crime as teenagers were also registered as adults. Among females registered for crime as youths, desistance was more common; two thirds did not appear again in the criminal register as adults, which is in line with the results reported by Moffitt et al. (2001) for example. The three groups defined on the basis of their criminality as youths and as adults respectively differ substantially from one another with regard to the frequency of their registered offending. As expected, a small group of offenders account for a large proportion of the registered offences. Altogether the group of males who continued to commit offences after their teenage years account for over 75 percent of the male cohort members' registered offences, while at the same time constituting eleven percent of the males in the cohort. Among the females, these individuals comprise one percent of the female cohort members but account for 46 percent of the females' registered offending. Looking at those cohort members who committed offences as both teenagers and adults, the level of offending among the males is significantly higher than that found among the females during the teenage period. During the adult period, however, the females in the group have on average been registered for just as many offences as the males (although the number of males in the group is substantially larger).

\section{TABLE 1 about here}

The cohort's offending, which has been described in previous studies, is dominated by theft, motoring and fraud offences (Wikström, 1987, 1990; Kratzer \& Hodgkins, 1999; see also tables in Nilsson \& Estrada, 2009). The clearest difference between the sexes in the crime mix (type of crime over the life span) is that the males are registered for motoring offences to a much greater extent, whereas fraud offences account for a larger proportion of the females' criminality. Crimes of violence constitute only a small proportion 
of the offences committed, irrespective of crime grouping. The individuals who continue to commit offences as adults do not distinguish themselves by being specialised in any particular type of offending. What differentiates the groups is thus first and foremost not the types of crime engaged in but rather the frequency of offending, and this is the case for both males and females. This pattern corresponds well with the findings of other studies (Stattin et al., 1989; Blokland et al., 2005, p. 945; Block et al., 2010).

\section{Drug abuse}

A large proportion of those who continue to commit offences subsequent to their teenage years are drug abusers (Table 2). This is particularly the case among the females; almost two thirds of the female persisters have been classified as drug abusers in the register data. The other two female offender groups also consist of significantly higher proportions of drug abusers by comparison with the corresponding groups of males. It is also noteworthy that most of the drug abusers are already known to the authorities as such when they are teenagers. Among the males and females who are first registered for crime as adults, however, the majority do not appear in the data as known drug abusers until after the age of 18 . Another factor which shows that drug abuse and criminality follow a similar developmental pattern is found in the fact that the proportion of desisters with registered drug abuse declines substantially after the teenage years. There are clear differences as regards the registers in which the different offender groups are found and this, at least in part, can be seen as a reflection of the seriousness of the addiction problem. Both the hospital and needle-mark registers describe more serious drug problems than those found in the files from the Child Welfare Committees.

Since we know that drug abuse is correlated with both criminality and adult social bonds we can expect these findings to have importance for the welfare situation in mid- 
life among male and female offenders. Before we study how their lives turned out, however, we will describe how life started for the girls and boys in the Stockholm cohort.

\section{Table 2 about here}

\section{Conditions during childhood and adolescence}

It is clear that the cohort members who have been registered for crime are more scarcely resourced. Among the persisters, around one-third had grown up in a family categorised as recurrently or chronically poor. The group who persisted in crime is in this regard different from the other two offender groups. There is a tendency in each of the three groups that had been registered for crime for the females to have experienced more poverty during childhood than the males (Table 3).

\section{Table 3 about here}

The SBC database also allows for an examination of the significance of childhood conditions which indicate more serious social problems. In the same way as in the case of financial difficulties, it is clear that the females who have been registered for crime tend to have experienced social problems in their childhood environments more often than the corresponding group of males. It seems as though the females who commit offences repeatedly constitute a more highly selected (poorly resourced) group than the corresponding group of males. It is important to note that it is only when we look at indicators of more direct and accumulated resource deficiencies that it becomes apparent that it takes more to become a female offender. 


\section{Family, work and social exclusion at age 48}

The final year to which we are able to follow the cohort in this study is 2001 , the year in which the cohort members celebrated their $48^{\text {th }}$ birthdays. However, of the entire cohort, approximately two percent had died prior to the age of 48 (Table 4). The mortality rate is approximately seven times as high (at 13 percent) among the male and female persisters by comparison with those who have not been registered for crime. ${ }^{9}$ It is worth noting that the mortality rate is not higher among the females in the persistent crime group than it is among the males. Among the desisters and the late onset group, the mortality rates are considerably lower than among the persisters.

At age 48, most of the men and women were living with others either as married couples or cohabitees (with children in common). They were also in employment, with middle to high incomes and very few were welfare benefit recipients (Table 4). The living conditions of the offenders were significantly worse however, with a large proportion living by themselves and on low incomes or no income at all. This pattern is more marked among the female cohort members. A majority of the females who had been registered for crime were registered as single at age 48 and this is particularly true among the female persisters, where only a small proportion (20 percent) were living with a partner. When the focus is directed at labour market attachment, we can see that among the women with no registered involvement in crime, 80 percent had established themselves on the labour market, which represents more or less the same level as that found among the men. Among the female desisters, the level of labour market attachment was also relatively high. However, for the female persisters it was as common to be on a disability pension as it was to be in employment. Among the males too, the degree of labour market attachment was markedly worse among the persisters, and at age

\footnotetext{
${ }^{9}$ The differences in mortality rates are underestimated somewhat since we can only study the SBC cohort, i.e. those who could be matched with more recent data (and who were thus alive in 1980).
} 
48, only half of them were counted among the core labour force. In late mid-life, 2-3 percent of the male and female cohort members were welfare benefit recipients. Among male and female persisters, this proportion is many times greater. The same pattern is found in relation

to disability pensions. There is a clear tendency among both males and females for those who had been registered for crime for the first time as adults to have living conditions that were better than those of the persisters, but worse than those of the desisters.

In table 4 we also present our summary measure of social exclusion (either outside the labour market or in receipt of social welfare benefit). Of the women registered for crime both during and subsequent to their teenage years, almost two-thirds meet this definition of social exclusion, compared to just under 40 percent of the males in the same group. The corresponding proportions are much lower among those who desisted from crime during their teenage years, who are therefore more reminiscent of those with no registered involvement in crime. Those who belong to the late onset group were living in social exclusion to a greater extent at age 48 , and the situation of the women was particularly unfavourable. In summary, it is worth noting that for every welfare outcome where there are clear differences between the males and females who have been registered for crime, these differences are to the disadvantage of the females. Why is this? We already know that a larger proportion of the females with registered involvement in crime were drug abusers, and it would therefore seem reasonable to examine this issue in more detail.

\section{Table 4 about here}

\section{Crime, drug abuse and social exclusion}

It is clear that drug abuse affects the risk of social exclusion for both sexes, even after controlling for involvement in crime (Table 5). Note for example that drug abusers with no 
official criminal record are more socially excluded than desisters with no known drug abuse. After controlling for drug abuse, the higher risk of social exclusion among females only remains for the small group of persistent offenders who are not drug users. This indicates that drug abuse has particular importance for both patterns of criminality and other life-course outcomes among females.

\section{Table 5 about here}

The differences in childhood circumstances that have been described in the article would alone be sufficient to expect to find worse outcomes in late mid-life among the females registered for involvement in crime (see e.g. Bäckman \& Nilsson, 2011). In addition, we have noted more extensive levels of drug abuse among females with a criminal record. Tables 6 and 7 present the results from logistic regression analyses which examine how the risk for social exclusion is linked to involvement in crime and gender, given controls for both differences in drug abuse and in other circumstances during childhood and adolescence. The focus is thus directed at the interaction between sex and the different offender categories. The dependant variable is the summary measure of social exclusion. The tables show odds-ratios using males with no registered involvement in crime as the reference category. In order to facilitate comparisons with the other groups, the tables also present confidence intervals for these odds-ratios. Table 6 shows that the groups who have been registered for crime as adults present a clear excess risk for social exclusion, even when controls are included for a range of circumstances experienced during childhood and adolescence, whereas the desisters do not differ significantly from the no-crime group. The table also shows that the only group of female offenders that differs from the corresponding group of males is the persisters. In Table 7, we have also included a control for drug abuse. As expected, the level of excess risk then 
declines for both the late onset group and the persisters. The female persisters remain the group at most risk of social exclusion, but the difference in relation to the male persisters is no longer significant.

\section{Table 6 and 7 about here}

\section{Concluding discussion}

Our main research question has centred on how life turned out for men and women with different forms of criminal involvement. Does it take more, in terms of childhood risk factors, and cost more, in terms of long-term negative consequences, to be a female offender? A finding common to both males and females is that those individuals who committed offences come from markedly worse childhood conditions. When we look at more direct indicators of social disadvantage during childhood (families marked by long term poverty and social problems) rather than more indirect indicators (SES), we also see that the backgrounds of the female offenders are characterised by more serious problems than those of their male counterparts. In this sense it "takes more" to become a female offender.

By contrast with what has been suggested by Tanner et al. (1999), our results indicate that the situation for female offenders is particularly problematic and that drug use is of significance to this difference. Our results are therefore more in line with the conclusions drawn on the basis of the research conducted by the Ohio Longitudinal Study (e.g. Giordano et al., 2002; Lanctot et al., 2007; Schroeder et al., 2007; Giordano, 2010). When we look at the cohort members' family situation and labour market attachment in late mid-life, the differences between those who desisted from crime in their teenage years and those with no registered offending is quite small. For those who were registered for crime as adults, however, the situation is more problematic, and this is particularly so for the females. The 
literature has indicated that the stigma of being registered for crime is greater for females than for males, which for example can make it more difficult for female offenders to find conventional males to live with (e.g. Steffensmeier \& Allan, 1996; De Li \& MacKenzie, 2003). Our study confirms that female offenders appear to be worse off in this regard, at least in late mid-life. Moreover, as adults the majority of the female persisters can be described as socially excluded; a large proportion is not in employment and are experiencing difficulties supporting themselves. Even though these things are also true of many of the men who persisted in offending into adulthood, it is important to note that in middle age, the majority of these men have some level of labour market attachment. Further, a large proportion of these men are involved in stable family relationships. This is not the case for the corresponding group of females. Among the desisters and the late onset group there is also a tendency for the situation as adults to be worse among the females. Thus it appears that involvement in crime exacts a higher cost for female offenders.

However, the fact that the situation of the female offenders is worse than that of the males is essentially associated with their more problematic backgrounds and their more extensive levels of drug abuse. When controls are included for differences in childhood conditions and drug abuse, female offenders do not differ from the corresponding male offender categories, which are to say that if we compare female offenders with male offenders presenting similar backgrounds and experiences of drug abuse, we see more similarities than differences between the two groups. In short, the same factors seem to produce the same longterm outcome for males and females. This is an important result because it suggests that it is the selection process that is most significant rather than the possibility that the negative consequences of involvement in crime are more pronounced for female offenders. To conclude, the existence of gendered pathways (Steffensmeier \& Allan, 1996; Simpson et al., 2008) becomes apparent when we look at indicators of more direct and accumulated resource 
deficiencies and drug abuse. This fact also underscores the argument of among others Farnworth, Thornberry, Krohn, and Lizotte (1994) that it is not sufficient to use broader categories such as SES as indicators of problematic living conditions. Moreover, even if both male and female drug users share the fate of social exclusion in mid-life we think that it is noteworthy that so many of the female offenders are registered as drug users. This is a finding in line with research that sees drug use as an important feature of both the causes and the outcome of persistent female criminality (Daly, 1992; Simpson et al., 2008) and at the same time a result life-course criminology has not paid enough attention to.

\section{Limitations}

The individuals we have studied were born in Sweden in 1953 and thus lived as youths during the 1960s and 1970s. What can we learn today from their experiences? When generalising on the basis of our findings, it is important to be aware of the fact that there are differences over time and between countries as regards the conditions that affect the prevalence of e.g. risk and protective factors, the social measures employed by a given society and also crime policy. However, we would argue that the specificity of the context of the Stockholm cohort is not a problem. In order to identify general processes that are not tied to a specific time or place, there is good reason to study the longer term consequences of childhood conditions, crime and drug abuse for individuals from a society that differs from those which dominate this field of research (see also Bersani, Laub, \& Nieuwbeerta 2009; Savolainen, 2009).

By utilising a longitudinal data set (The Stockholm Birth Cohort, SBC) we have been able, primarily on the basis of various forms of register data, to follow a large number of males and females from childhood into adult life. This has made it possible to analyse questions that have previously been difficult to examine. Our study is limited however by problems which are already widely acknowledged. Our conclusions about gendered pathways 
and consequences relate only to those offences that are detected and registered by the criminal justice system. As has been noted by Steffensmeier and Allan (1996) sex differences are smaller in studies based on self-report data, but these data also tend often to describe less serious forms of involvement in crime by comparison with the criminality that becomes the object of justice system interventions. Although we have been able to use indicators relating to a range of different childhood and living conditions, there remain important areas that we have not been able to examine, including for example the significance of childhood trauma and sexual abuse as precursors to offending and vulnerability to abuse from men. These have been identified as important factors in relation to the understanding of gendered pathways and consequences (Daly, 1992; Belknap \& Holsinger, 2006; Cernkovich, Lanctot, \& Giordano, 2008; Simpson et al., 2008).

One question that we are interested in examining in future studies focuses on the within-group variation among those registered for involvement in crime: what differentiates the males and females for whom things turned out well from those for whom things went badly? What are the roles played by childhood conditions, events occurring later in life, and society's responses to their criminality, and in what way does the significance of different live events vary between males and females? 


\section{References}

Belknap, J. \& Holsinger, K. (2006). The gendered nature of risk factors for delinquency. Feminist Criminology, 1, 48-71.

Bergman, L. \& Andershed, A-K. (2009). Predictors and Outcomes of Persistent or AgeLimited Registered Criminal Behaviour: A 30-Year Longitudinal Study of a Swedish Urban Population. Aggressive Behaviour, 35, 164-178.

Bersani, B., Laub, J., \& Nieuwbeerta, P. (2009). Marriage and Desistance from Crime in the Netherlands: Do Gender and Sociohistorical Context Matter? Journal of Quantitative Criminology, 25, 3-24.

Block, C., Blokland, A., van der Werff, C., van Os, R. \& Nieuwbeerta, P. (2010). Long-term patterns of offending in women. Feminist Criminology, 5, 73-107.

Blokland, A., Nagin, D. \& Nieuwbeerta, P. (2005). Life Span Offending Trajectories of a Dutch Conviction Cohort. Criminology, 43, 919-954.

Burchardt, T. (2000). Social exclusion: Concepts and evidence. In D. Gordon, \& P. Townsend (Eds), Breadline Europe. The measurement of poverty. Bristol: Policy Press, 385-405.

Bäckman, O. \& Nilsson, A. (2011). Pathways to Social Exclusion. European Sociological Review, 27, 107-123.

Cernkovich, S., Lanctot, N. \& Giordano, P. (2008). Predicting adolescent and adult antisocial behaviour among adjudicated delinquent females. Crime and Delinquency, 54, 3-33.

Daly, K. (1992). Women's pathways to felony court: Feminist theories of lawbreaking and problems of representation. Review of Law and Women's Studies, 2, 11-52.

De Li, S. \& MacKenzie, D. (2003). The gendered effects of adult social bonds on the criminal activities of probationers. Criminal Justice Review, 28, 278-298.

Eggleston, E. \& Laub, J. (2002). The onset of adult offending: A neglected dimension of the criminal career. Journal of Criminal Justice, 30, 603-622. 
Farnworth, M., Thornberry, T., Krohn, M. \& Lizotte, A. (1994). Measurement in the Study of Class and Delinquency: Integrating Theory and Research. Journal of Research in Crime and Delinquency, 31, 32-61.

Farrington, D., Coid, J., Harnett, L., Jolliffe, D., Soteriou, N., Turner, R. \& West, D. (2006). Criminal careers up to age 50 and life success up to age 48: new findings from the Cambridge Study in Delinquent Development. $2^{\text {nd }}$ edition. Home Office Research Studies, London.

Farrington, D., Tfofi, M. \& Coid, J. (2009). Development of Adolescence-limited, Late-onset, and Persistent offenders from age 8 to age 48. Aggressive Behaviour, 35, 150-63.

Fry, L. (1985): Drug abuse and Crime in a Swedish Birth Cohort. British Journal of Criminology, 25, 46-59.

Gorman-Smith, D. \& Loeber, R. (2005). Are developmental pathways in disruptive behaviors the same for girls and boys? Journal of Child and Family Studies, 14, 15-27.

Giordano, P., Cernkovich, S. \& Rudolph, J. (2002). Gender, crime and desistance: toward a theory of cognitive transformation. American Journal of Sociology, 107, 990-1064.

Giordano, P. (2010). Legacies of Crime. A Follow-Up of the Children of Highly Delinquent Girls and Boys. Cambridge University Press: New York.

Hagan, J. \& McCarthy, B. (1997). Mean streets. Cambridge: Cambridge University Press. Heidensohn, F. (1968). The deviance of women: a critique and an enquiry. British Journal of Sociology, 19, 160-175.

Holsinger, K. (2000). Feminist perspectives on female offending. Women \& Criminal Justice, $12,23-51$.

Jansson, C-G. (1995).On Project Metropolitan and the Longitudinal Perspective. Project Metropolitan, research report no 40. Stockholm: Department of Sociology, Stockholm University. 
Katz, R. (2000). Explaining girls' and women's crime and desistance in the context of their victimization experiences. Violence Against Women, 6, 633-660.

Kratzer, L. \& Hodgkins, S. (1999). A typology of offenders: a test of Moffitt's theory among males and females from childhood to age 30. Criminal Behaviour and Mental Health, 9, $57-73$.

Krohn, M., Lizotte, A. \& Perez, C. (1997). The Interrelationship Between Substance Use and Precocious Transitions to Adult Statuses. Journal of Health and Social Behaviour, 38, 87-103.

Kyvsgaard, B. (1989). Og faengslet tar de sidste (And prison take the last. Criminality, punishment and living conditions, in Danish). Denmark: Jurist-og okonomforbundets forlag.

Lanctot, N., Cernkovich, S. \& Giordano, P. (2007). Delinquent behaviour, official delinquency and gender: Consequences for adulthood functioning and well-being. Criminology, 45, 131-157.

Laub, J., Nagin, D. \& Sampson, R. (1998). Trajectories of Change in Criminal Offending: Good Marriages and the Desistance Process. American Sociological Review, 63, 225238.

Laub, J \& Sampson, R (2003). Shared Beginnings, Divergent Lives. Delinquent Boys to Age 70. Harvard University Press: Cambridge, Massachusetts.

Lay, B., Ihle, W., Esser, G. \& Schmidt, M. (2005). Juvenile-episodic, Continued or Adultonset Delinquency? Risk conditions analysed in a cohort of children followed up to the age of 25 years. European Journal of Criminology, 2, 36-66.

Lenke, L. \& Olsson, B. (2002). Swedish Drug Policy in the Twenty-First Century: A Policy Model Going Astray. The ANNALS of the American Academy of Political and Social Science, 582, 64-79. 
Moffitt, T., Caspi, A., Rutter, M \& Silva, P. (2001). Sex differences in antisocial behaviour. Conduct disorder, delinquency and violence in the Dunedin Longitudinal Study. Cambridge university press.

Molero Samuelsson, Y. (2011). Antisocial behaviour over the life course among females and males treated for substance misuse. Karolinska institutet.

Mullings, J., Pollock, J. \& Crouch, B. (2002). Drugs and criminality: Results from the Texas women inmates study. Women \& Criminal Justice, 13, 69-96.

Nilsson, A. (2003). Living Conditions, Social Exclusion and Recidivism among Prison Inmates, Journal of Scandinavian Studies in Criminology and Crime Prevention, 4, $57-$ 83.

Nilsson, A. \& Estrada, F. (2009). Criminality and life chances. A longitudinal study of crime, childhood circumstances and living conditions to age 48. Report 2009:3. Department of Criminology, Stockholm university.

Odgers, C., Moffitt, T., Broadbent, J., Dickson, N., Hancox, R., Harrington, H., Poulton,R., Sears, M., Thomson, M., \& Caspi, A. (2008). Female and male antisocial trajectories: From childhood origins to adult outcomes. Development and Psychopathology, 20, 673716.

Piquero, A., Farrington, D., Nagin, D \& Moffitt, T. (2010). Trajectories of offending and their relations to life failure in late middle age: findings from the Cambridge study in delinquent development. Journal of Research in Crime and Delinquency, 47, 151-173.

Pulkinnen, L, Lyyra, A.L. \& Kokko, K. (2009). Life Success of Males on Non-offender, Adolescence-Limited, Persistent, and Adult-Onset Antisocial Pathways: Follow up from age 8 to 42. Aggressive Behaviour, 35, 117-135.

Sampson, R. \& Laub, J. (1993). Crime in the Making. Pathways and Turning Points through Life. Cambridge: Harvard University Press. 
Sarnecki, J. \& Sollenhag, S. (1985). Predicting Social Maladjustment. Stockholm Boys Grown up. Report no 17, The National Council for Crime Prevention.

Savolainen, J. (2009). Work, Family and Criminal Desistance. British Journal of Criminology, 49, 285-304.

Schroeder, R., Giordano, P. \& Cernkovich, S. (2007). Drug use and desistance processes. Criminology, 45, 191-222.

Simpson, S., Yahner, J. \& Dugan, L. (2008). Understanding women’s pathways to jail: Analysing the lives of incarcerated women. The Australian and New Zealand Journal of Criminology, 41, 84-108.

Skardhamar, T. (2010). Distinguishing facts and artefacts in group-based modelling. Criminology, 48, 295-320.

Soothill, K., Christoffersen, M., Hussain, M. \& Francis, B. (2010). Exploring paradigms of crime reduction. An Empirical Longitudinal Study. British Journal of Criminology, 50, $222-238$.

Stattin, H., Magnusson, D. \& Reichel, H. (1989). Criminal activity at different ages. A study based on a Swedish Longitudinal Research Population. British Journal of Criminology, $29,368-385$

Steffensmeier, D. \& Allan, E. (1996). Gender and Crime: Toward a gendered theory of female offending. Annual Review of Sociology, 22, 459-487.

Stenberg, S-Å. \& Vågerö, D. (2006). Cohort Profile: The Stockholm birth cohort of 1953. International Journal of Epidemiology, 35, 546-548.

Stenberg, S-Å., Vågerö, D., Österman, R., Arvidsson, E., von Otter, C. \& Jansson, C-G. (2007). Stockholm Birth Cohort Study 1953-2003: A new tool for life course studies. Scandinavian Journal of Public Health, 35, 104-110. 
Tanner, J., Davies, S. \& O'Grady B. (1999). Whatever happened to yesterday's rebels? Longitudinal effects of youth delinquency on education and employment. Social Problems, 46, 250-274.

Torstensson, M. (1987). Drug-Abusers in a Metropolitan Cohort. Project Metropolitan research report No 25, Department of Sociology, University of Stockholm.

Torstensson, M. (1990). Female delinquents in a birth cohort: test of some aspects of control theory. Journal of Quantitative Criminology, 6, 101-115.

Wikström, P-O. (1987). Patterns of crime in a birth cohort. Age, sex and social class differences. Project Metropolitan research report No 24, Department of Sociology, University of Stockholm.

Wikström, P-O. (1990). Age and crime in a Stockholm cohort. Journal of Quantitative Criminology, 6, 61-84.

Wong, T., Slotboom, A-M. \& Bijleveld, C. (2010). Risk factors for delinquency in adolescent and young adult females. A European review. European Journal of Criminology, 7, 266284. 


\section{Tables}

Table 1. Proportion (percent) in crime register and mean number of crimes by age, gender and categories of offenders. Females ( $\mathrm{N}=6989)$, males $(\mathrm{N}=7305)$, (NO=Number of offences).

\begin{tabular}{|c|c|c|c|c|c|c|}
\hline & \multicolumn{2}{|c|}{ Desisters } & \multicolumn{2}{|c|}{ Late onset } & \multicolumn{2}{|c|}{ Persisters } \\
\hline & Male & Female & Male & Female & Male & Female \\
\hline $\begin{array}{l}\text { Percent } \\
\text { (N) }\end{array}$ & $\begin{array}{l}11.8 \\
(859)\end{array}$ & $\begin{array}{l}2.6 \\
(181)\end{array}$ & $\begin{array}{l}10.6 \\
(777)\end{array}$ & $\begin{array}{l}3.1 \\
(216)\end{array}$ & $\begin{array}{l}11.0 \\
(803)\end{array}$ & $\begin{array}{l}1.3 \\
(89)\end{array}$ \\
\hline Mean offences as young & 3.4 & $2.2+$ & - & - & 11.7 & $3.6+$ \\
\hline Proportion of youth offences females $(\mathrm{NO}=720)$ & - & 55 & - & - & - & 45 \\
\hline Proportion of youth offences males $(\mathrm{NO}=12336)$ & 24 & - & - & - & 76 & - \\
\hline Mean offences as adult & - & - & 3.3 & $4.7+$ & 12.4 & 13.0 \\
\hline Proportion of adult offences females $(\mathrm{NO}=2173)$ & - & - & - & 54 & - & 46 \\
\hline Proportion of adult offences males $(\mathrm{NO}=12534)$ & - & - & 20 & - & 80 & - \\
\hline
\end{tabular}

+ Female offender group differs from corresponding male offender group $(\mathrm{p}<.05)$

Table 2. Proportion (percent) registered for drug abuse between ages 13 and 30, by gender, categories of offenders and source of information, $(\mathrm{N})$.

\begin{tabular}{llllll}
\hline & No crime & Desisters & Late onset & Persisters & Total \\
\hline Females & $(6503)$ & $(181)$ & $(216)$ & $(89)$ & $(6989)$ \\
Drug abuse total 13-30 (n=6989) & 0.8 & $19.9^{*}+$ & $19.4^{*}+$ & $60.7^{*}+$ & 2.6 \\
Drug abuse 13-30 according to: & & & & & 1.9 \\
Social register (13-18 years) & 0.6 & $18.2^{*}+$ & $10.2^{*}+$ & $43.8^{*}+$ & 1.1 \\
Hospital register (13-30 years) & 0.2 & $4.4^{*}+$ & $11.6^{*}+$ & $31.5^{*}+$ & 1.0 \\
Needle mark study (15-30 years) & 0.1 & $5.0^{*}+$ & $9.7^{*}+$ & $42.7^{*}+$ & 2.0 \\
Drug abuse 13-18 years & 0.6 & $18.2^{*}+$ & $11.6^{*}+$ & $47.2^{*}+$ & 1.3 \\
Drug abuse 19-30 years & 0.2 & $5.0^{*}+$ & $13.4^{*}+$ & $43.8^{*}+$ & $(7305)$ \\
Males & $(4866)$ & $(859)$ & $(777)$ & $(803)$ & 4.6 \\
Drug abuse total 13-30 (n=7305) & 0.6 & $4.3^{*}$ & $4.1^{*}$ & $29.5^{*}$ & 3.0 \\
Drug abuse 13-30 according to: & & & & & 1.7 \\
Social register (13-18 years) & 0.4 & $3.3^{*}$ & $1.4^{*}$ & $19.8^{*}$ & $1.3^{*}$ \\
Hospital register (13-30 years) & 0.2 & $0.8^{*}$ & $2.1^{*}$ & 18.7 & 2.4 \\
Needle mark study (15-30 years) & 0.0 & $0.8^{*}$ & $2.6^{*}$ & $22.2^{*}$ & 3.3 \\
Drug abuse 13-18 years & 0.4 & $3.7^{*}$ & $1.4^{*}$ & $3.3^{*}$ & $20.4^{*}$ \\
Drug abuse 19-30 years & 0.2 & $0.9^{*}$ & & 2.8 \\
\hline
\end{tabular}

+ Female offender group differs from corresponding male offender group $(\mathrm{p}<.05)$

* Offender group differs from non offenders $(\mathrm{p}<.05)$ 
Table 3. Childhood conditions, proportion (percent) by gender and categories of offenders, $(\mathrm{N})$.

\begin{tabular}{|c|c|c|c|c|c|}
\hline & No crime & Desisters & Late onset & Persisters & Total \\
\hline Females & $(6503)$ & $(181)$ & (216) & (89) & $(6989)$ \\
\hline \multicolumn{6}{|l|}{ Social class } \\
\hline Upper and upper-middle class & 17.5 & 13.9 & 17.6 & $9.1 *$ & 17.3 \\
\hline Lower middle class & 44.4 & $36.1 *$ & $32.4 *+$ & $34.1^{*}$ & 43.7 \\
\hline Skilled blue-collar & 22.5 & 25.6 & 26.4 & 25.0 & 22.7 \\
\hline Unskilled blue-collar & 15.5 & $24.4 *$ & $23.6^{*}$ & $31.8^{*}$ & 16.2 \\
\hline \multicolumn{6}{|l|}{ Poverty } \\
\hline Non-poor & 81.6 & $64.1 *$ & $67.1 *+$ & $42.7 *+$ & 80.2 \\
\hline Transient poor & 8.9 & $13.3^{*}$ & 11.1 & $19.1^{*}$ & 9.2 \\
\hline Recurrent poor & 5.4 & $11.6^{*}$ & $12.5^{*}+$ & $21.3^{*}$ & 6.0 \\
\hline Chronic poor & 4.1 & $11.0^{*}+$ & $9.3^{*}$ & $16.9^{*}$ & 4.6 \\
\hline \multicolumn{6}{|l|}{ Social problems family of origin } \\
\hline Alcohol abuse parents & 5.4 & $14.9 *+$ & $13.9 *+$ & $24.7 *$ & 6.2 \\
\hline Mental health problems parents & 5.6 & $12.7 *$ & $11.1 *$ & $25.8^{*}$ & 6.2 \\
\hline Father registered for crime & 5.2 & $11.0^{*}$ & $8.8^{*}$ & $23.6^{*}+$ & 5.7 \\
\hline At least one social problem & 12,8 & $27,6^{*}+$ & $23,6^{*}+$ & $53,9^{*}+$ & 14,1 \\
\hline Males & $(4866)$ & (859) & (777) & $(803)$ & $(7305)$ \\
\hline \multicolumn{6}{|l|}{ Social class } \\
\hline Upper and upper-middle class & 19.9 & $11.5^{*}$ & $14.6^{*}$ & $7.5^{*}$ & 17.0 \\
\hline Lower middle class & 44.8 & $40.9^{*}$ & 42.3 & $34.8^{*}$ & 43.0 \\
\hline Skilled blue-collar & 21.1 & $24.7^{*}$ & 23.8 & $30.8^{*}$ & 22.9 \\
\hline Unskilled blue-collar & 14.3 & $22.9^{*}$ & $19.3^{*}$ & $27.0^{*}$ & 17.2 \\
\hline \multicolumn{6}{|l|}{ Poverty } \\
\hline Non-poor & 84.0 & $69.5^{*}$ & $76.1^{*}$ & $55.0^{*}$ & 78.3 \\
\hline Transient poor & 8.9 & $13.6^{*}$ & $11.2^{*}$ & $18.1^{*}$ & 10.7 \\
\hline Recurrent poor & 4.4 & $10.1^{*}$ & $6.3^{*}$ & $14.1^{*}$ & 6.3 \\
\hline Chronic poor & 2.8 & $6.8^{*}$ & $6.4^{*}$ & $12.8^{*}$ & 4.7 \\
\hline \multicolumn{6}{|l|}{ Social problems family of origin } \\
\hline Alcohol abuse parents & 4.0 & $9.2^{*}$ & $7.2^{*}$ & $18.7^{*}$ & 6.5 \\
\hline Mental health problems parents & 4.8 & $10.2^{*}$ & $7.3^{*}$ & $14.8^{*}$ & 6.8 \\
\hline Father registered for crime & 3.6 & $7.5^{*}$ & $6.3 *$ & $10.3^{*}$ & 5.1 \\
\hline At least one social problem & 9,8 & $20,8^{*}$ & $15,1^{*}$ & $32,9^{*}$ & 14,2 \\
\hline
\end{tabular}

+ Female offender group differs from corresponding male offender group $(\mathrm{p}<.05)$

* Offender group differs from non offenders $(\mathrm{p}<.05)$ 
Table 4. Family type, employment status, income and mortality at 48 years of age (2001) by gender and categories of offenders, $(\mathrm{N})$.

\begin{tabular}{|c|c|c|c|c|c|}
\hline & No crime & Desisters & Late onset & Persisters & Total \\
\hline \multicolumn{6}{|l|}{$\underline{\text { Females }}$} \\
\hline \multicolumn{6}{|l|}{ Mortality } \\
\hline \multirow[t]{2}{*}{ Deceased by age 48} & 1.7 & $5.0 *$ & $4.6^{*}$ & $13.5^{*}$ & 2.0 \\
\hline & $(6208)$ & $(166)$ & $(203)$ & $(76)$ & $(6653)$ \\
\hline \multicolumn{6}{|l|}{ Family type } \\
\hline Single with children & 19.0 & $24.1+$ & $28.1^{*}+$ & $30.3 *+$ & 19.5 \\
\hline Single without children & 21.0 & 27.1 & $35.0^{*}+$ & $48.7 *$ & 21.9 \\
\hline Married or cohabiting with children & 48.3 & $33.7 *+$ & $32.5^{*}+$ & $17.1 *+$ & 47.1 \\
\hline Married or cohabiting without children & 11.7 & $15.1+$ & $4.4^{*}$ & $3.9 *$ & 11.5 \\
\hline \multicolumn{6}{|l|}{ Labour market attachment } \\
\hline In employment (core labour force) & 80.3 & $68.7 *+$ & $59.6^{*}+$ & $36.8 *+$ & 78.9 \\
\hline Studying & 1.5 & $1.8+$ & 1.5 & 2.6 & 1.5 \\
\hline Unstable labour market attachment & 8.3 & $12.7 *+$ & 10.3 & 5.3 & 8.4 \\
\hline No labour market attachment & 5.2 & 5.4 & $11.3^{*}$ & $19.7 *$ & 5.5 \\
\hline Disability pension & 4.7 & $11.4 *+$ & $17.2 *$ & $35.5 *+$ & 5.6 \\
\hline \multicolumn{6}{|l|}{ Income and welfare benefit } \\
\hline \multicolumn{6}{|l|}{ Income } \\
\hline Low income $(<20 \%)$ & 19.7 & $31.3 *+$ & $40.4^{*}+$ & $63.2 *+$ & 21.1 \\
\hline Middle income & 69.5 & $60.8 *$ & $53.7 *$ & $35.5 *$ & 68.4 \\
\hline High income $(>20 \%)$ & 10.8 & $7.8+$ & $5.9 *+$ & $1.3^{*}+$ & 10.5 \\
\hline Social exclusion & 10.6 & $18.1 *+$ & $32.0^{*}+$ & $61.8^{*}+$ & 12,0 \\
\hline \multicolumn{6}{|l|}{$\underline{\text { Males }}$} \\
\hline \multicolumn{6}{|l|}{ Mortality } \\
\hline \multirow[t]{2}{*}{ Deceased by age 48} & 2.1 & $3.3^{*}$ & $4.8^{*}$ & $12.7 *$ & 3.7 \\
\hline & $(4647)$ & $(815)$ & $(719)$ & $(684)$ & $(6865)$ \\
\hline \multicolumn{6}{|l|}{ Family type } \\
\hline Single parent & 7.0 & $9.1 *$ & 7.1 & $10.3 *$ & 7.6 \\
\hline Single without children & 28.2 & $34.8 *$ & $42.8 *$ & $52.5^{*}$ & 32.9 \\
\hline Married or cohabiting with children & 56.9 & $46.7 *$ & $42.6^{*}$ & $30.9 *$ & 51.6 \\
\hline Married or cohabiting without children & 8.0 & 9.3 & 7.5 & $6.3 *$ & 7.9 \\
\hline \multicolumn{6}{|l|}{ Labour market attachment } \\
\hline In employment (core labour force) & 86.4 & $81.8 *$ & $71.3 *$ & $53.9 *$ & 81.1 \\
\hline Studying & 0.5 & 0.4 & 0.6 & $1.2 *$ & 0.5 \\
\hline Unstable labour market attachment & 4.9 & $7.0 *$ & $8.5^{*}$ & $9.2 *$ & 6.0 \\
\hline No labour market attachment & 4.5 & 6.0 & $11.0^{*}$ & $18.1 *$ & 6.7 \\
\hline Disability pension & 3.7 & 4.8 & $8.6^{*}$ & $17.5^{*}$ & 5.7 \\
\hline \multicolumn{6}{|l|}{ Income and welfare benefit } \\
\hline Welfare benefit recipient & 0.9 & $2.3^{*}$ & $3.9 *$ & $13.6^{*}$ & 2.6 \\
\hline \multicolumn{6}{|l|}{ Income } \\
\hline Low income $(<20 \%)$ & 13.6 & $18.2 *$ & $28.7 *$ & $46.2 *$ & 18.9 \\
\hline Middle income & 50.5 & $61.0 *$ & $55.1 *$ & $46.4^{*}$ & 51.8 \\
\hline High income $(>20 \%)$ & 36.0 & $20.9 *$ & $16.3 *$ & $7.4^{*}$ & 29.3 \\
\hline Social exclusion & 8.5 & $11.8 *$ & $20.6^{*}$ & $39.0 *$ & 13,2 \\
\hline
\end{tabular}

+ Female offender group differs from corresponding male offender group $(\mathrm{p}<.05)$

* Offender group differs from non offenders $(\mathrm{p}<.05)$ 
Table 5. Social exclusion (2001) and drug use (1966-1983). Proportion (percent) who at age 48 were either in receipt of social welfare benefits or who had no attachment to the labour market and proportion registered for drug abuse between ages 13 and 30, by gender, categories of offenders and drug use, $(\mathrm{N})$.

\begin{tabular}{llllll}
\hline & No crime & Desisters & Late onset & Persisters & Total \\
\hline$\underline{\text { Females }}$ & $(6208)$ & $(166)$ & $(203)$ & $(76)$ & $(6653)$ \\
$\begin{array}{l}\text { Social exclusion and drug use } \\
\text { Exclusion among non users }\end{array}$ & 10.5 & $14.0^{*+}$ & $26.2^{*+}$ & $53.1^{*}+$ & 11.2 \\
Exclusion among drug users & 25.0 & $36.7 *$ & $60.0^{*}$ & $68.2^{*}$ & 47.1 \\
Males & $(4647)$ & $(815)$ & $(719)$ & $(684)$ & $(6865)$ \\
$\begin{array}{l}\text { Social exclusion and drug use } \\
\text { Exclusion among non users } \\
\text { Exclusion among drug users }\end{array}$ & 8.4 & $11.0^{*}$ & $19.1^{*}$ & $30.1 *$ & 11.5 \\
\hline
\end{tabular}

* Group differs from male non offenders $(\mathrm{p}<.05)$

+ Female offender group differs from corresponding male offender group $(\mathrm{p}<.05)$

Note: All differences in social exclusion between non drug users and users are significant $(\mathrm{p}<.05)$ except among female persistent offenders.

Table 6. The risk for social exclusion at age 48. Interaction effects of sex and offender category. Results from logistic regression models. Odds ratios (95\% C.I.). Controls included for: poverty family of origin, parents alcohol abuse, parents mental health problems, father registered for crime, social class, IQ, and grades in year 9 of compulsory school, $\mathrm{N}=12051$.

\begin{tabular}{lcccc}
\hline & No crime & Desisters & Late onset & Persisters \\
\hline Male & $\mathbf{1}$ & 1.22 & $2.55^{*}$ & $4.94^{*}$ \\
Female & & $(0.94-1.59)$ & $(2.03-3.21)$ & $(3.88-5.99)$ \\
& $1.28^{*}$ & $1.93^{*}$ & $4.33^{*}$ & $12.20^{*}+$ \\
& $(1.11-1.48)$ & $(1.23-3.03)$ & $(3.12-6.25)$ & $(6.72-19.08)$ \\
\hline
\end{tabular}

* Group differs from male non offenders $(\mathrm{p}<.05)$

+ Female offender group differs from corresponding male offender group $(\mathrm{p}<.05)$

Table 7. The risk for social exclusion at age 48. Interaction effects of sex and offender category. Results from logistic regression models. Odds ratios (95\% C.I.). Controls included for: poverty family of origin, parents alcohol abuse, parents mental health problems, father registered for crime, social class, IQ, and grades in year 9 of compulsory school, and drug abuse, $\mathrm{N}=12051$.

\begin{tabular}{lcccc}
\hline & No crime & Desisters & Late onset & Persisters \\
\hline Male & $\mathbf{1}$ & 1.15 & $2.47^{*}$ & $3.67^{*}$ \\
& & $(0.88-1.51)$ & $(1.96-3.11)$ & $(2.91-4.62)$ \\
Female & $1.28^{*}$ & 1.45 & $3.56^{*}$ & $6.29^{*}$ \\
& $(1.11-1.48)$ & $(0.91-2.32)$ & $(2.48-5.10)$ & $(3.60-10.99)$ \\
\hline
\end{tabular}

* Group differs from male non offenders $(\mathrm{p}<.05)$ 
Appendix

\begin{tabular}{|c|c|c|c|c|}
\hline $\begin{array}{l}\text { Variables (order } \\
\text { of appearance) }\end{array}$ & $\begin{array}{l}\text { Source (for construction of } \\
\text { variable) }\end{array}$ & Variable description & $\begin{array}{l}\text { Further } \\
\text { information* }\end{array}$ & $\begin{array}{l}\text { Cohort } \\
\text { age }\end{array}$ \\
\hline $\begin{array}{l}\text { Categories of } \\
\text { offenders }\end{array}$ & National crime register 1966-1984 & See article text & Codebook IV & $13-31$ \\
\hline Drug abuse & $\begin{array}{l}\text { Drug abuse in the Social register } \\
\text { 1966-1971. Drug related diagnosis } \\
\text { in the in-patient discharge register } \\
\text { 1966-1983. The injection mark } \\
\text { study: data on intravenous drug } \\
\text { abuse in the Stockholm police } \\
\text { arrest population 1968-1983. }\end{array}$ & $\begin{array}{l}0=\text { No indications in register } \\
1=\text { At least one indication in } \\
\text { one of the sources }\end{array}$ & Codebook II, IV, V & $13-30$ \\
\hline $\begin{array}{l}\text { Social class (mostly } \\
\text { fathers occupation) }\end{array}$ & Population register 1963 & $\begin{array}{l}\text { 1=Upper middle class } \\
\text { 2=Lower middle class } \\
3=\text { Skilled workers } \\
\text { 4=Unskilled workers }\end{array}$ & Codebook II & 10 \\
\hline Poverty & $\begin{array}{l}\text { Social register. Receipt of means } \\
\text { tested social assistance benefit } \\
\text { during 1953-59 and/or 1960-65 } \\
\text { and/or 1966-72. }\end{array}$ & $\begin{array}{l}1=\text { No indications in register } \\
2=\text { Received one period } \\
3=\text { Received two periods } \\
4=\text { Received all three } \\
\text { periods }\end{array}$ & Codebook II & $0-19$ \\
\hline $\begin{array}{l}\text { Parents' alcohol } \\
\text { problems }\end{array}$ & $\begin{array}{l}\text { Incidents of drunkenness of parent } \\
\text { according to the Social Register } \\
1953-72\end{array}$ & $\begin{array}{l}0=\text { No incidents } \\
1=\text { One or more incidents }\end{array}$ & Codebook II & $0-19$ \\
\hline $\begin{array}{l}\text { Parents' } \\
\text { psychological } \\
\text { problems }\end{array}$ & $\begin{array}{l}\text { Mother or father showing } \\
\text { symptoms of mental illness } \\
\text { according to the Social Register } \\
\text { 1953-1972 }\end{array}$ & $\begin{array}{l}0=\text { No symptoms } \\
1=\text { Show symptoms on one } \\
\text { or more occasions }\end{array}$ & Codebook II & $0-19$ \\
\hline Father's criminality & National crime register $1953-1972$ & $\begin{array}{l}0=\text { No convictions } \\
1=\text { One or more convictions }\end{array}$ & Codebook IV & $0-19$ \\
\hline Mortality & $\begin{array}{l}\text { The causes of death register 1981- } \\
2001\end{array}$ & $\begin{array}{l}0=\text { No indication in register } \\
1=\text { Dead }\end{array}$ & Codebook VI & $27-48$ \\
\hline Family type & $\begin{array}{l}\text { Longitudinal Database on } \\
\text { Education, Income and } \\
\text { Occupation (LOUISE) }\end{array}$ & $\begin{array}{l}1=\text { Single parent } \\
2=\text { Single without children } \\
3=\text { Married or cohab. with } \\
\text { children } \\
\begin{array}{l}4=\text { Married or cohab. without } \\
\text { children }\end{array}\end{array}$ & Codebook VI & 48 \\
\hline Employment & LOUISE & See article text & Codebook VI & 48 \\
\hline Welfare benefit & LOUISE & $\begin{array}{l}0=\text { No indications in register } \\
1=\text { At least one indication }\end{array}$ & Codebook VI & 48 \\
\hline Income & LOUISE & $\begin{array}{l}\text { 1=Low income } \\
\text { 2=Middle income } \\
3=\text { High income }\end{array}$ & Codebook VI & 48 \\
\hline Social exclusion & LOUISE & $\begin{array}{l}0=\text { Not socially excluded } \\
1=\text { Either outside the labour } \\
\text { market or in receipt of social } \\
\text { welfare benefit }\end{array}$ & Codebook VI & 48 \\
\hline $\begin{array}{l}\text { Educational } \\
\text { achievement } \\
\text { (age 16) }\end{array}$ & $\begin{array}{l}\text { Records from the School boards of } \\
\text { Stockholm City and Stockholm } \\
\text { County } 1969 \text { (1966) }\end{array}$ & $\begin{array}{l}\text { Grade score average from } \\
\text { the ninth grade (ranging 1- } \\
5 \text { ). Where data is missing, } \\
\text { grade scores from the sixth } \\
\text { grade have been used. }\end{array}$ & Codebook II & 16 \\
\hline $\begin{array}{l}\text { Cognitive ability / } \\
\text { IQ }\end{array}$ & The School Study 1966 & $\begin{array}{l}\text { Continuous variable based } \\
\text { on results from cognitive } \\
\text { tests }\end{array}$ & Codebook I & 13 \\
\hline
\end{tabular}

* Codebooks available at www.stockholmbirthcohort.su.se 